\title{
Synthesis of Fe Nanoparticles Using Biological and Chemical Methods and Its Application
}

\author{
R. Thyagarajan, S. Pradeep Kumar, V. Ramesh Kumar, \\ and G. Narendrakumar
}

Department of Biotechnology,

School of Bio and Chemical Engineering,

Sathyabama Institute of Science and Technology (Deemed to be University), Jeppiaar Nagar, Rajiv Gandhi Salai,

Chennai-600119, Tamilnadu, India

Nanotechnology can be defined as the manipulation of matter through certain chemical, physical, or biological processes to create materials with specific properties, which can be used in particular applications. Ferrous nanoparticles have been synthesized biologically using extract obtained from the plant Phyllanthus acidus. The extract has been added to a solution of ferrous salt and has been incubated for 24 hours at room temperature to facilitate the formation of Fe nanoparticles. Nanoparticles have been synthesized chemically by the reduction of ferrous salt using a strong reducing agent in presence of a stabilizing agent. The synthesis of Fe particles has been confirmed by UV-Vis spectroscopy analysis. The absorption spectra showed the presence of nanoparticles. FTIR analysis has been done to study the changes in organic groups present in the plant extract. FESEM images show size and morphology of synthesized nanoparticles. The photocatalytic activity of synthesized nanoparticles has been studied using certain industrial dyes. Using these nanoparticles, industrial effluent like effluents of dye industry can be treated to degrade toxic dyes.

Нанотехнологію можна визначити як маніпулювання речовиною за допомогою певних хемічних, фізичних або біологічних процесів для створення матеріялів зі специфічними властивостями, які можуть використовуватися в конкретних застосуваннях. Залізні наночастинки синтезуються біологічно з використанням екстракту, одержаного 3 рослини Phyllanthus acidus (філлантус кислий). Екстракт додавали до розчину солі заліза й інкубували протягом 24 годин за кімнатної температури для полегшення утворення наночастиц Fе. Хемічно наночастинки були синтезовані шляхом відновлення солі заліза з використанням сильного відновника в присутності стабілізувального агента. Синтезу частинок Fе підтверджено спектроскопічною аналізою в ультрафіолетовому та видимому 
діяпазонах. Спектри поглинання показали наявність наночастинок. Аналізу Фур'є-образів у спектроскопії інфрачервоного діяпазону було проведено для вивчення змін в органічних групах, що є присутніми у рослинному екстракті. Зображення сканувальної електронної мікроскопіі польової емісії показують розмір і морфологію синтезованих наночастинок. Фотокаталітична активність синтезованих наночастинок вивчалася з використанням деяких промислових барвників. Використовуючи ці наночастинки, промислові відходи, такі як стічні води фарбувальної промисловости, можна обробляти, щоб руйнувати токсичні барвники.

Нанотехнологию можно определить как манипулирование веществом посредством определённых химических, физических или биологических процессов для создания материалов со специфическими свойствами, которые могут использоваться в конкретных приложениях. Железные наночастицы синтезируются биологически с использованием экстракта, полученного из растения Phyllanthus acidus (филлантус кислый). Экстракт добавляли к раствору соли железа и инкубировали в течение 24 часов при комнатной температуре для облегчения образования наночастиц Fе. Химически наночастицы были синтезированы путём восстановления соли железа с использованием сильного восстановителя в присутствии стабилизирующего агента. Синтез частиц Fе подтверждён спектроскопическим анализом в ультрафиолетовом и видимом диапазонах. Спектры поглощения показали наличие наночастиц. Анализ фурье-образов в спектроскопии инфракрасного диапазона был проведён для изучения изменений в органических группах, присутствующих в растительном экстракте. Изображения сканирующей электронной микроскопии полевой эмиссии показывают размер и морфологию синтезированных наночастиц. Фотокаталитическая активность синтезированных наночастиц изучалась с использованием некоторых промышленных красителей. Используя эти наночастицы, промышленные отходы, такие как сточные воды красильной промышленности, можно обрабатывать, чтобы разрушать токсичные красители.

Key words: nanoparticles, ferrous Phyllanthus acidus, ferric chloride, photocatalytic activity, dyes.

Ключові слова: наночастинки, залізистий філлантус кислий, хлорид заліза, фотокаталітична активність, барвники.

Ключевые слова: наночастицы, железистый филлантус кислый, железо, хлорид железа, фотокаталитическая активность, красители.

(Received 25 September, 2018)

\section{INTRODUCTION}

Nanotechnology can be defined as the manipulation of matter through certain chemical and/or physical processes to create materials with specific properties, which can be used in particular applications. A nanoparticle can be defined as a microscopic particle that has at least one 
dimension less than 100 nanometres in size. Unlike bulk materials, they have unique optical, thermal, electrical, chemical, and physical properties and, hence, they find a variety of applications in the areas of medicine, chemistry, environment, energy, agriculture, information, and communication, heavy industry and consumer goods. Many different numbers of ways can synthesize nanoparticles. However, they have been classified into three different ways. They are physical methods, chemical methods, and biological methods. For this study, chemical methods and biological methods were used.

The noble metallic nanoparticles may be incorporated for numerous applications in different fields like electronics, microscopy, biomedicines and textile. In textile and paper industry recently, ferrous nanoparticles are used to degrade the organic dyes as they exhibit enhanced photocatalytic property for degrading organic dyes under solar radiation. Recent reports suggest that the removal of organic dyes using $\mathrm{Fe}$ nanoparticles is a better choice than the common dye removal techniques like redox treatment, electro-coagulation, carbon sorption and UV photodegradation (Kaushik Roy et al., 2015).

Dyes are a major class of synthetic organic compounds used in variety of applications. One of the applications of dyes is in textile industries, which consumes about $60 \%$ of total dye production for coloration of various fabrics. Moreover, after the completion of their use, nearly $15 \%$ of dyes are wasted. These dye compounds dissolve in water bodies with a concentration in between 10 and 200 milligram per litre results in significant water pollution worldwide. Therefore, treatment of dye effluents from textile industries is a mandatory part of wastewater treatment. The release of dye effluents in aquatic systems is major environmental concern because coloration not only decreases sunlight penetration and dissolved oxygen in water bodies, but also releases toxic compounds during chemical or biological reaction pathway that affects aquatic flora and fauna. These nanoparticles are used extensively in the degradation of these textile effluent dyes (Ravindra et al., 2016).

\section{MATERIALS AND METHODS}

\subsection{Chemicals}

Ferric chloride, sodium borohydride, trisodium citrate dihydrate, rhodamine B (powder), methylene blue (powder). All the chemicals were bought from Merck, India.

\subsection{Collection of Plant Sample}

The leaves of Phyllanthus acidus was collected from a garden in Chen- 
nai district, Tamilnadu, India. After the collection of leaves, they were washed well in running tap water twice. Then, they were washed in distilled water and preserved. Only fresh and healthy leaves were taken for the study. After washing, the leaves were used for the preparation of the extract.

\subsection{Preparation of the Extract}

The well-cleaned fresh leaves were taken for the preparation of the plant extract. 20 grams of leaves was taken and was finely chopped. The finely chopped leaves were taken in a $100 \mathrm{ml}$ beaker and $100 \mathrm{ml}$ of distilled water was added. Then, the leaves with water were boiled at $80^{\circ} \mathrm{C}$ for 45 minutes. Then, the extract is taken and allowed to cool. Then, the extract is filtered in Whatmann No. 1 filter paper. This extract is used as a reducing agent for the synthesis of nanoparticles.

\subsection{Biological Synthesis}

The ferric chloride solution was prepared in a $250 \mathrm{ml}$ conical flask. The molarity of the solution taken is 0.1 M. 1.622 grams of ferric chloride in $100 \mathrm{ml}$ of distilled water. $90 \mathrm{ml}$ of $0.1 \mathrm{M}$ ferric chloride solution was taken in a $250 \mathrm{ml}$ clean conical flask. $10 \mathrm{ml}$ of the prepared plant extract is added to the ferric chloride solution. On addition of the plant extract, immediate colour change from light orange to black is observed instantaneously. Then, the nanoparticle solution is incubated at $30^{\circ} \mathrm{C}$ for 24 hours. After the 24 hours, the nanoparticle is separated from the solution. Figures 1 and 2 show the colour change process during the formation of Fe nanoparticles (Sangiliyandi Gurunathan et al., 2015).

\subsection{Chemical Synthesis}

In chemical method, $0.1 \mathrm{M}$ of ferric chloride is used to synthesis of na-

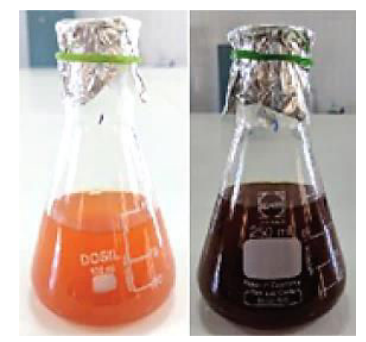

Fig. 1. This is the $0.1 \mathrm{M}$ of ferric chloride solution before addition of plant extract. 


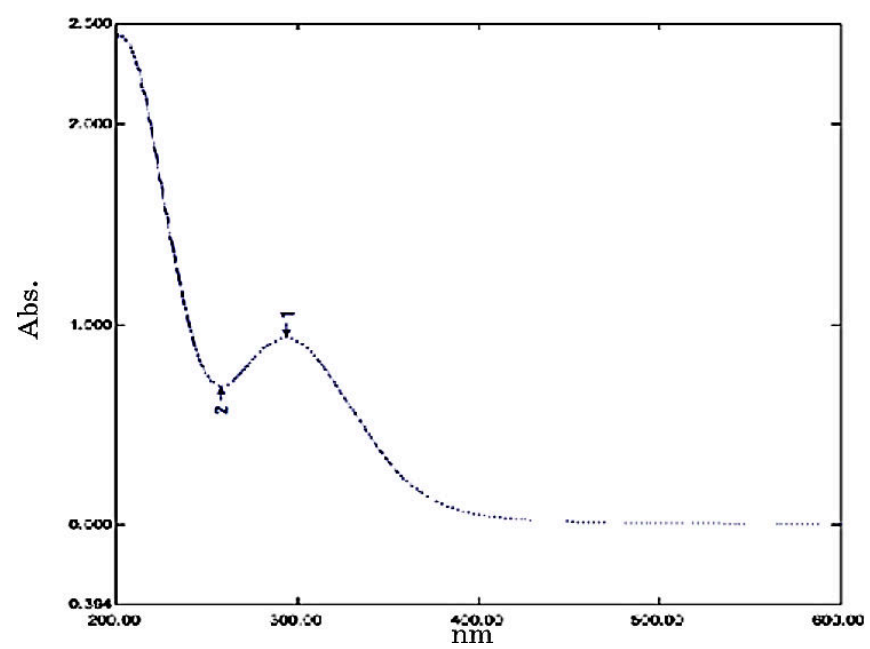

Fig. 2. UV-Vis spectroscopy analysis of biologically synthesized Fe nanoparticle that has a peak at $294 \mathrm{~nm}$.

noparticles. The reducing agent used is sodium borohydride. The molarity of the sodium borohydride used is 2.5 M. 1.89 grams of sodium borohydride is dissolved in $20 \mathrm{ml}$ of distilled water. $0.1 \mathrm{M}$ ferric chloride is prepared by dissolving 1.622 grams in $100 \mathrm{ml}$ of distilled water. In this method, trisodium citrate dihydrate is used as a stabilizing agent. Molarity of trisodium citrate dihydrate is $75 \mathrm{mM}$. 2.205 grams of trisodium citrate dihydrate is used. Now, $80 \mathrm{ml}$ of $0.1 \mathrm{M}$ ferric chloride is taken in clean $250 \mathrm{ml}$ conical flask. 2.205 grams of trisodium citrate dihydrate is dissolved in ferric chloride solution. Then, $20 \mathrm{ml}$ of sodium borohydride is added slowly accompanied by continuous stirring. This addition of reducing agent is accompanied by formation of bubbles. After the addition of $20 \mathrm{ml}$ of sodium borohydride, the colour change can be observed from light orange to dark black. Once the bubble formation ceases, that assumed reaction is complete. Then, the solution is incubated at $30^{\circ} \mathrm{C}$ for 24 hours. After the 24 hours, the nanoparticle is separated from the solution was represented by the colour change process during the formation of Fe nanoparticles (Yuvakkumar et al., 2011).

\subsection{Separation and Drying of Nanoparticles}

After 24 hours of incubation, the solution of the nanoparticle is centrifuged at $3000 \mathrm{rpm}$ for 15 minutes. The supernatant is discarded. The pellet is the nanoparticle. The pellet is washed with distilled water for 2 to 3 times. Then, the pellet is collected and is freeze dried in a lyophilizer overnight. After drying, the nanoparticle powder is used for fur- 
ther analysis and application (Brajesh Kumar et al., 2015).

\subsection{Characterization of Fe Nanoparticles}

After drying, the Fe nanoparticles are characterized using various studies like UV-Vis spectroscopy, Fourier-transform infrared (FTIR) spectroscopy and field emission scanning electron microscopy (FESEM) analyses. The sample is centrifuged and the pellet along with some liquid portion is given for UV-Vis spectroscopy analysis. For the FTIR and FESEM analyses, the sample is given in the form of dry powder. For FTIR of the control sample, the plant extract is lyophilized and given in the form of powder.

\subsection{Photocatalytic Activity}

\subsubsection{Methylene blue}

The nanoparticle is analysed for its photocatalytic activity. Photocatalytic activity is defined as the degradation activity in presence of sunlight. The degradation capability of nanoparticles for the textile industry dyes in presence of sunlight is analysed. The dyes like methylene blue and rhodamine B (basic violet) were used for the experiment.

Methylene blue has a formula $\mathrm{C}_{16} \mathrm{H}_{18} \mathrm{ClN}_{3} \mathrm{~S}$. The stock solution was prepared by dissolving 1 gram of methylene blue powder in $100 \mathrm{ml}$ distilled water. Then, $1 \mathrm{ml}$ of the solution was taken and added in $9 \mathrm{ml}$ distilled water, which is stock 2 . Then, $1 \mathrm{ml}$ of solution from stock 2 is taken and added to $99 \mathrm{ml}$ of distilled water, which is working standard. The concentration of working solution is $10 \mathrm{mg} / \mathrm{l} .3$ tubes were taken labelled as A, B, C. $10 \mathrm{ml}$ of working standard is taken in each of the three tubes. A is control 1, which has no nanoparticles and is kept in sunlight, which is approximately $30^{\circ} \mathrm{C}$. B is control 2 , in which $5 \mathrm{mg}$ of nanoparticles are added, and is kept in dark. $\mathrm{C}$ is test, in which $5 \mathrm{mg}$ of nanoparticles are added and kept under sunlight irradiation. All the three tubes were incubated for 6 hours. The solutions were centrifuged, and clear supernatant is collected and reading was taken in a colorimeter at $620 \mathrm{~nm}$, one hour once. The readings showed gradual decrease in reading for the test indicating the degradation of the dye. The readings were recorded and tabulated (Herrera et al., 2016).

\subsubsection{Rhodamine B}

Rhodamine B dyes' degradation by nanoparticle was studied in the same way as methylene blue. Rhodamine $\mathrm{B}$ formula is $\mathrm{C}_{28} \mathrm{H}_{31} \mathrm{ClN}_{2} \mathrm{O}_{3}$. The stock solution was prepared by dissolving 1 gram of methylene blue powder in 
$100 \mathrm{ml}$ distilled water. Then, $1 \mathrm{ml}$ of the solution was taken and added in $9 \mathrm{ml}$ distilled water that is stock 2 . Then, $1 \mathrm{ml}$ of solution from stock 2 is taken and added to $99 \mathrm{ml}$ of distilled water that is working standard. The concentration of working solution is $10 \mathrm{mg} / \mathrm{l}$. Here, five tubes were taken labelled as A, B, C, D, E. $10 \mathrm{ml}$ of working standard is taken in each of the tubes. Tube A is control 1, which has no nanoparticles but is kept in sunlight. Tube B is control 2, which has $5 \mathrm{mg}$ of nanoparticles and is kept in dark. Tubes C, D, E have nanoparticles in concentration of $5 \mathrm{mg}, 10 \mathrm{mg}, 15 \mathrm{mg}$, respectively. Each of them was kept under sunlight irradiation. The tubes were incubated in respective conditions for 6 hours. The solution was centrifuged, clear supernatant is collected, and reading was taken in a colorimeter at $540 \mathrm{~nm}$, one hour once. The readings were recorded and tabulated (Herrera et al., 2016).

\subsection{Percentage of Degradation}

The percentage of degradation was calculated using the formula:

$$
D=\left(A_{o}-A_{i}\right) /\left(100 A_{o}\right),
$$

where $D$-percentage of degradation; $A_{o}$-initial OD reading; $A_{i}$-OD reading at $i^{\text {th }}$ hour.

The percentage of degradation was calculated using the above formula for every hour and a graph is plotted taking time on $x$-axis and percentage of degradation on $y$-axis. The curve obtained gives the efficiency of nanoparticle to degrade dyes.

\section{RESULTS AND DISCUSSION}

\subsection{UV-Vis Spectroscopy}

Ultraviolet-visible spectroscopy refers to absorption spectroscopy or reflectance spectroscopy in the ultraviolet-visible spectral region. This means it uses light in the visible and adjacent ranges. The absorption or reflectance in the visible range directly affects the perceived colour of the chemicals involved. In this region of the electromagnetic spectrum, atoms and molecules undergo electronic transitions. This spectroscopy helps in identification of presence of nanoparticles. The nanoparticles give unique absorption spectra over the range of wavelengths. The instrument used is Shimadzu UV-1800, Japan.

\subsubsection{Biologically synthesized Fe nanoparticle}

The nanoparticle synthesized by biological method using plant extract 
was analysed using UV-Vis spectroscopy at the range of 200 to 800 $\mathrm{nm}$. Figure 2 represents the UV-Vis absorption spectra of biologically synthesized nanoparticle. The nanoparticle gave a sharp absorption peak at $294 \mathrm{~nm}$. This indicates the presence of nanoparticle in the solution. Studies from Yuvakkumar et al. (2011) in synthesis of Fe nanoparticles had a UV-Vis absorption peak at $268 \mathrm{~nm}$.

\subsubsection{Chemically synthesized Fe nanoparticles}

The nanoparticle synthesized by chemical method using sodium borohydride as reducing agent and trisodium citrate dihydrate as stabilizing agent was analysed using UV-Vis spectroscopy. Figure 3 represents the UV-Vis absorption spectra of chemically synthesized nanoparticle. This nanoparticle did not show a sharp absorption peak but gave a continuous absorption spectrum over the range of wavelength from 200-800 $\mathrm{nm}$. This shows the presence of nanoparticle in the sample. The study of Yen Pin Yew et al. (2016) in the synthesis of Fe nanoparticle using Kappaphycus alavarezii also reported a continuous absorption spectrum in the range of 200 to $800 \mathrm{~nm}$.

\subsection{Fourier-Transform Infrared Spectroscopy}

In nanoparticle, FTIR analysis will help to find out whichever chemical groups helped in the fabrication and stabilization of the nanoparticles. For the analysis, the sample is given in the powder form. The instrument used is Alpha spectrometer, US.

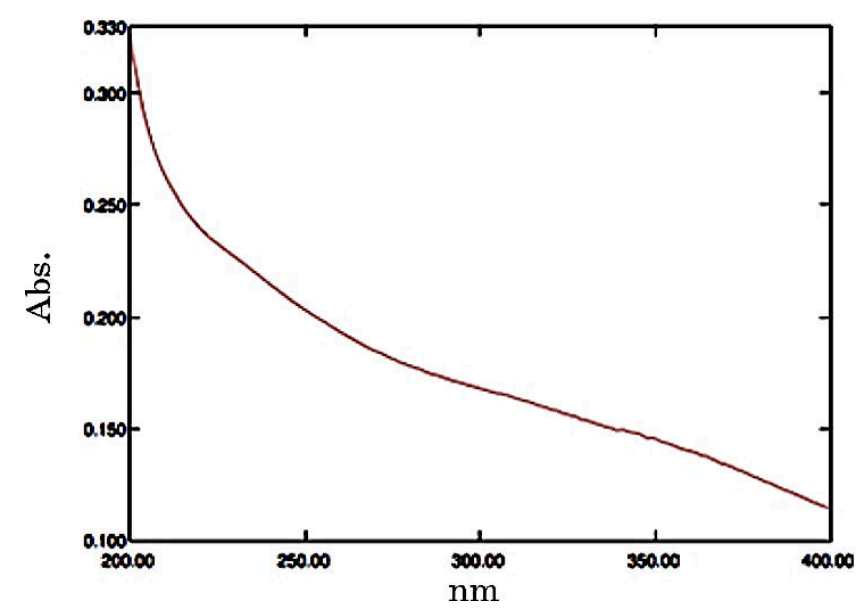

Fig. 3. UV-Vis spectroscopy of chemically synthesized Fe nanoparticle showing a continuous absorption spectrum over the wavelength of 200 to $400 \mathrm{~nm}$. 


\subsubsection{Biologically synthesized Fe nanoparticle}

The synthesized nanoparticle is analysed in the FTIR instrument and is taken as test. The control used for this analysis is the plant extract, which was lyophilized and analysed in powder form. The comparison between control and test shows the various chemical groups involved in the formation of nanoparticles. Figures 4 and 5 represent the FTIR spectra of control and test, respectively.

The peak at $3446 \mathrm{~cm}^{-1}$ in control and peak at $3404 \mathrm{~cm}^{-1}$ indicates a hy-

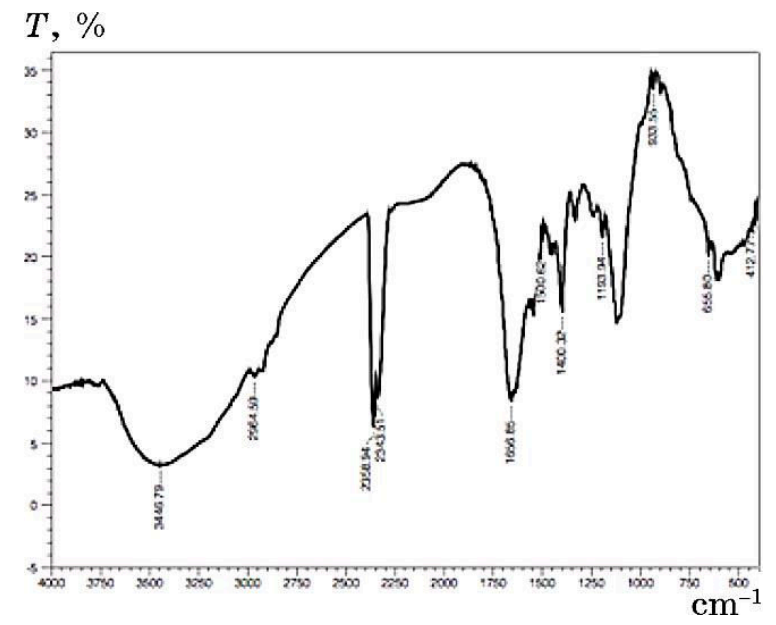

Fig. 4. FTIR analysis of the plant extract (control) showing various functional groups present in them.

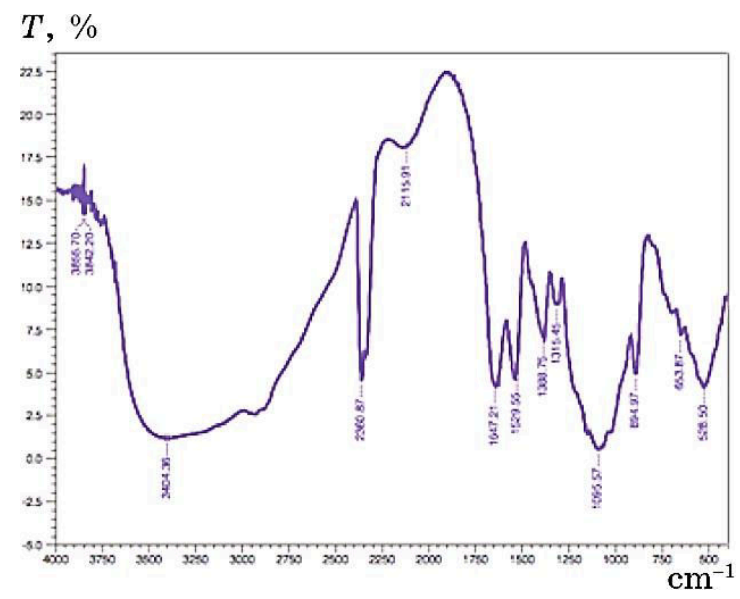

Fig. 5. FTIR analysis of the biologically synthesized Fe nanoparticle (test) shows various functional groups aided in the formation of Fe nanoparticle. 
droxyl group. This shows a compound in the plant extract that has a hydroxyl group as a functional group acted as reducing agent and has involved in the formation and stabilization of the nanoparticle. Likewise, the peak at $1656 \mathrm{~cm}^{-1}$ in control and at $1647 \mathrm{~cm}^{-1}$ in test indicates a carboxylic group. Again, this shows that a compound in plant extract having carboxylic group has functioned as a reducing agent and helped in formation and stabilization of nanoparticle. In the same way, the peaks at $1400 \mathrm{~cm}^{-1}$ in control and at $1388 \mathrm{~cm}^{-1}$ in test indicate a ketone group. A compound in the extract, which has a ketone group, has involved in the formation and stabilization of nanoparticle. By comparing the peaks in both test and control, the conclusion was determined from various compounds present in the plant that extract has involved as a reducing agent and helped in the formation and stabilization of the nanoparticles. Studies of Ting Wang et al. (2014) in synthesis of Fe nanoparticles using Eucalyptus leaves show similar bands and peaks.

\subsubsection{Chemically synthesized Fe nanoparticle}

The nanoparticle, which was synthesized using sodium borohydride as a reducing agent, was analysed using FTIR, and the results were obtained. Figure 6 indicates the FTIR analysis of the chemically synthesized nanoparticle. The sample was given in the powder form for the analysis. The results show the various chemical groups involved in the formation of nanoparticles.

The peaks at the range of $1600-1800 \mathrm{~cm}^{-1}$ correspond to ketone bond

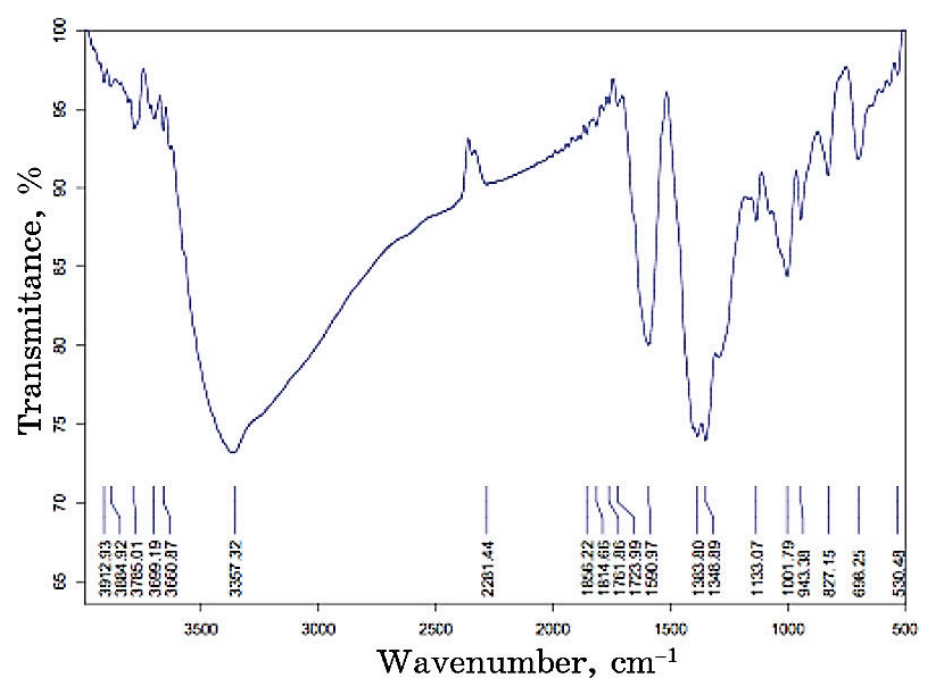

Fig. 6. FTIR analysis of chemically synthesized Fe nanoparticle showing various groups involved in the formation $\mathrm{Fe}$ nanoparticle. 
stretch. Especially, peaks at $1723 \mathrm{~cm}^{-1}$ and $1761 \mathrm{~cm}^{-1}$ indicate the carboxylic acid group. This confirms the involvement of trisodium citrate dihydrate in the stabilization of the nanoparticle. The peaks at the range of $600-1000 \mathrm{~cm}^{-1}$ correspond to alkyl bending, which again confirms that trisodium citrate is involved in stabilization of nanoparticles. Thus, FTIR analysis shows the various chemical groups in reducing agent and stabilizing agent involved in the fabrication and stabilization of the Fe nanoparticle. Studies of Chaki et al. (2015) synthesis of Fe nanoparticles using sodium borohydride as reducing agent reported similar peaks and bands.

\subsection{Field Emission Scanning Electron Microscopy}

Scanning electron microscope is used to know the size, shape and morphology of the synthesized nanoparticle. The image shows both the approximate size and the morphology of the nanoparticle. Since Fe nanoparticles are magnetic in nature, they cannot be analysed using normal SEM because the electromagnetic lenses produce a magnetic field within the instrument that will disturb the nanoparticles being analysed making them to agglomerate, and exact size of the nanoparticle cannot be identified. Therefore, these Fe nanoparticles are analysed using FESEM.

\subsubsection{Biologically synthesized Fe nanoparticle}

The nanoparticle synthesizes using biological method is analysed using FESEM to know the size and the morphology of the nanoparticle. The sample was given in the form of powder. Figure 7 shows the FESEM

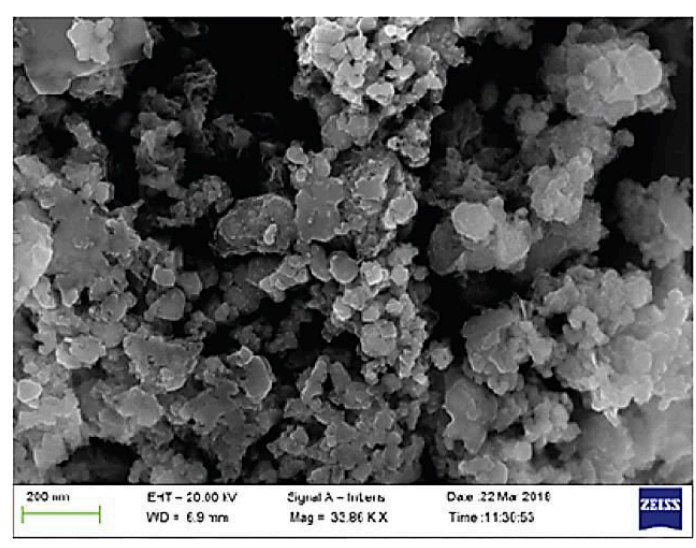

Fig. 7. FESEM image of biologically synthesized Fe nanoparticle showing the morphology and the size of the nanoparticle. 
image of the biologically synthesized nanoparticle. The image shows that the nanoparticles are of various shapes and show amorphous morphology. The size of nanoparticle ranges from $20 \mathrm{~nm}$ to $50 \mathrm{~nm}$ showing average diameter of $36 \mathrm{~nm}$. The size of the nanoparticle was found using software called ImageJ. Studies of Yen Pin Yew et al. for the synthesis of Fe nanoparticles using seaweed extract obtained a mean diameter of $28 \mathrm{~nm}$.

\subsubsection{Chemically synthesized Fe nanoparticle}

The nanoparticle synthesizes using chemical method is analysed using FESEM to know the size and the morphology of the nanoparticle. The sample was given in the form of powder. Figure 8 shows the FESEM image of the chemically synthesized nanoparticle. The image shows that the nanoparticle is of various shapes but mostly of circular morphology. The size of nanoparticle ranges from $20 \mathrm{~nm}$ to $40 \mathrm{~nm}$ with an average diameter of $24 \mathrm{~nm}$. The size of the nanoparticle was found using software called ImageJ. The image was uploaded in the software and its mean particle diameter was calculated. The scale required is set in software after uploading the image. The software identifies individual particle boundaries, and its size is measured. The result is obtained in the preset scale. The study of Sneha Shah et al. in the synthesis of Fe nanoparticles had obtained Fe nanoparticle of mean diameter of $17 \mathrm{~nm}$.

\subsection{Photocatalytic Activity}

The photocatalytic activity of the synthesized nanoparticles has been analysed using two dyes. The degradation capability of the synthesized nanoparticles in presence of sunlight has been analysed and the results

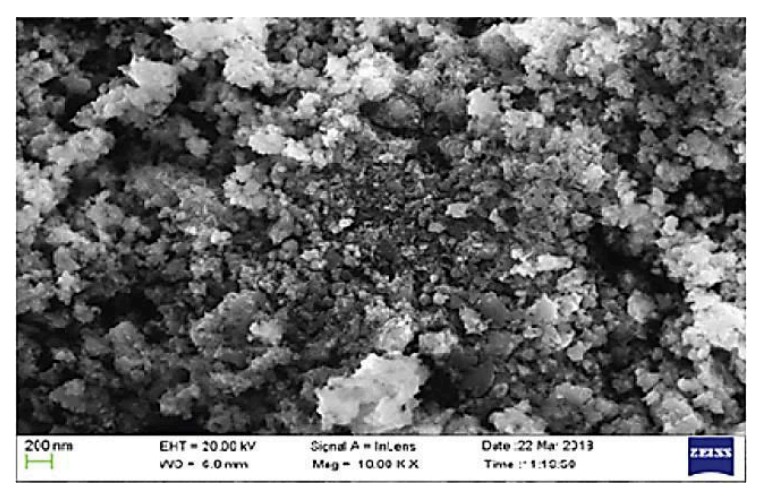

Fig. 8. FESEM image of chemically synthesized Fe nanoparticle showing the morphology and the size of the nanoparticle. 
are recorded. The activity is calculated in percentage and is represented in form of a graph. The graph shows the dye degrading capacity of the nanoparticle in assistance of sunlight. The percentage of degradation for the nanoparticles is calculated using a formula specified in methods section. The readings were taken in colorimeter for every hour and suing those readings percentage of degradation was calculated accordingly. A graph was plotted taking time in hours on $x$-axis and percentage of degradation on $y$-axis.

\subsubsection{Biologically synthesized Fe nanoparticles}

Figures 9-12 show the graphs representing the photocatalytic activity of biologically synthesized nanoparticles. Sample 15 presents the activity of nanoparticles for methylene blue dye and sample 18 represents activity of nanoparticles for rhodamine B dye.

\subsubsection{Methylene blue}

The graph 15 shows the photocatalytic activity of nanoparticle for methylene blue dye. There are three curves representing three different conditions. The first curve $C_{1}$ (control 1) represents dye solution along with $5 \mathrm{mg}$ of nanoparticle kept in dark condition. The second curve $C_{2}$ (control 2) represents dye solution alone kept in direct sunlight. The third curve $\mathrm{T}$ (test) represents dye solution along with $5 \mathrm{mg}$

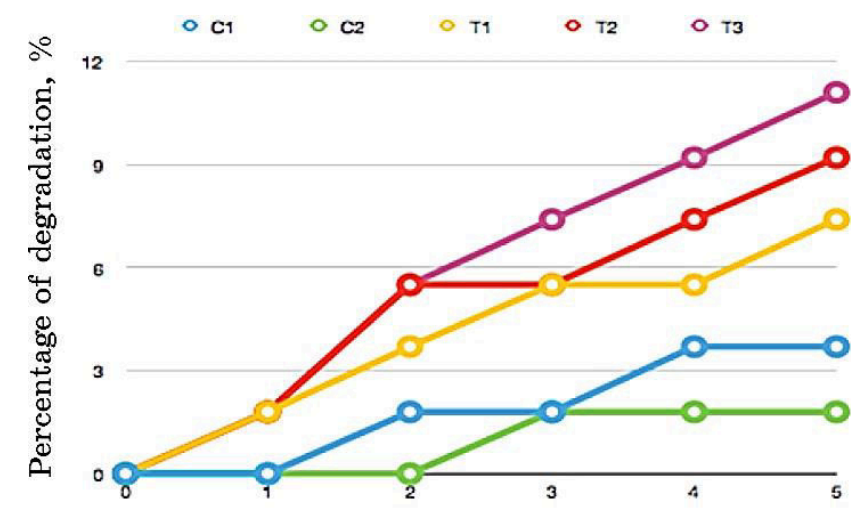

Time, hours

$C_{1}$-Dye solution $+5 \mathrm{mg}$ nanoparticle (dark incubation); $\mathrm{C}_{2}$-Dye solution (sunlight incubation);

$T_{1}$-Dye solution $+5 \mathrm{mg}$ nanoparticle (sunlight incubation).

Fig. 9. The graph showing the photocatalytic activity of the biologically synthesized Fe nanoparticle on methylene blue dye. 


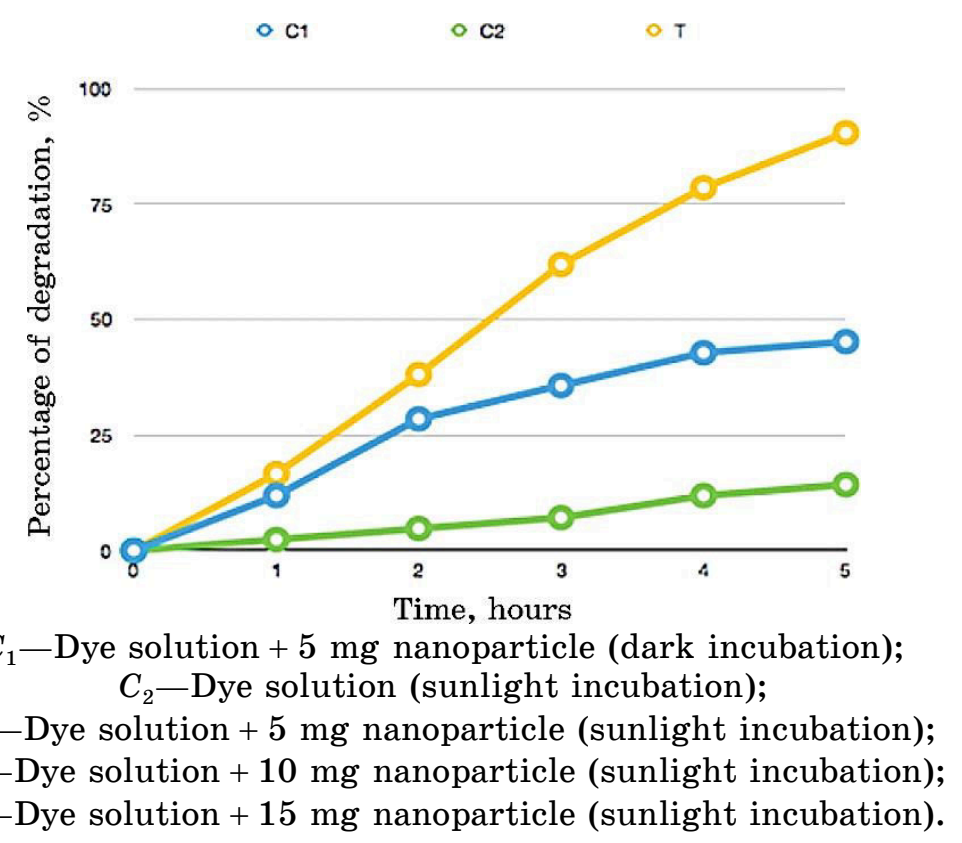

Fig. 10. The graph showing the photocatalytic activity of the biologically synthesized Fe nanoparticle on rhodamine B dye.

nanoparticle kept in direct sunlight. The absorbance of the solutions was read at $620 \mathrm{~nm}$ for every hour. The images 13 and 14 show the colour of the methylene blue dye at $0^{\text {th }}$ hour and at $5^{\text {th }}$ hour.

From these Figures, test sample gave maximum degradation percentage of $90.4 \%$ in 5 hours and it increases linearly every hour. In the same time, $C_{1}$ and $C_{2}$ have a degradation percentage of $45.2 \%$ and $14.2 \%$, respectively. It is clear that the nanoparticle has a degradation activity against methylene blue dye solution, and its activity or the degrading capability is enhanced by sunlight. The sunlight activates the nanoparticle and enhances its degrading ability. Therefore, biologically synthesized nanoparticle has a degrading activity of $90.4 \%$ in 5 hours against methylene blue dye. The colour reduction of methylene blue in a time span of 5 hours. Studies of A. Herrea et al. (2016) in photocatalytic activity of Fe nanoparticles on phenol obtained $89.1 \%$ degradation efficiency.

\subsubsection{Rhodamine B}

Figure 12 represents the photocatalytic activity of the nanoparticle against rhodamine B dye. There are five curves in the graph. The curve C1 (control 1) represents dye solution along with $5 \mathrm{mg}$ of nanoparticle 


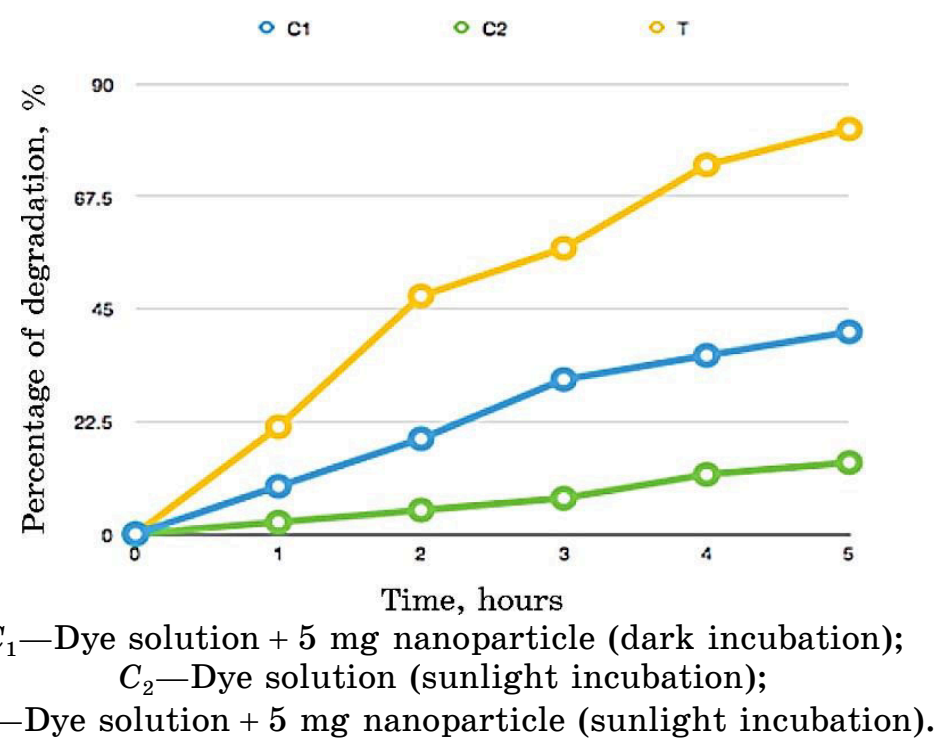

Fig. 11. The graph showing the photocatalytic activity of the chemically synthesized Fe nanoparticle on methylene blue dye.

kept in dark condition. The curve $C_{2}$ (control 2) represents dye solution alone kept in direct sunlight. The curves $T_{1}, T_{2}, T_{3}$ represent the dye solution along with $5 \mathrm{mg}, 10 \mathrm{mg}, 15 \mathrm{mg}$ of nanoparticle respectively kept in direct sunlight. The readings were taken at $540 \mathrm{~nm}$ in a colorimeter for every hour. The images 16 and 17 show the colour of the rhodamine $\mathrm{B}$ dye at $0^{\text {th }}$ hour and at $5^{\text {th }}$ hours.

From this Figure, it is evident that the nanoparticle has very lesser activity for rhodamine B than that for methylene blue. Even when the concentration of nanoparticle is increased up to 3 times, the nanoparticle showed maximum degradation percentage of $11.1 \%$ in 5 hours. The nanoparticle has very much less activity or no activity against rhodamine B. This study shows that the photocatalytic activity of the nanoparticle is limited. The nanoparticle does not degrade all dyes. The nanoparticle has the ability to degrade only simple dyes like methylene blue, which has the formula $\mathrm{C}_{16} \mathrm{H}_{18} \mathrm{ClN}_{3} \mathrm{~S}$. Complex dyes like rhodamine $\mathrm{B}$, which is having a formula of $\mathrm{C}_{28} \mathrm{H}_{31} \mathrm{ClN}_{2} \mathrm{O}_{3}$, cannot be degraded. The degradation of dyes depends upon the number of carbon atoms that the dye has. Lesser the number of carbons, the dye can be easily degraded by Fe nanoparticle. However, if the number of carbons in the atoms is more, the dye cannot be degraded by the nanoparticle. The photocatalytic activity of the Fe nanoparticle is limited, and it depends on the number of carbon atoms that the dye molecule has the colour reduction of rhodamine B dye in the time span of 5 hours. 


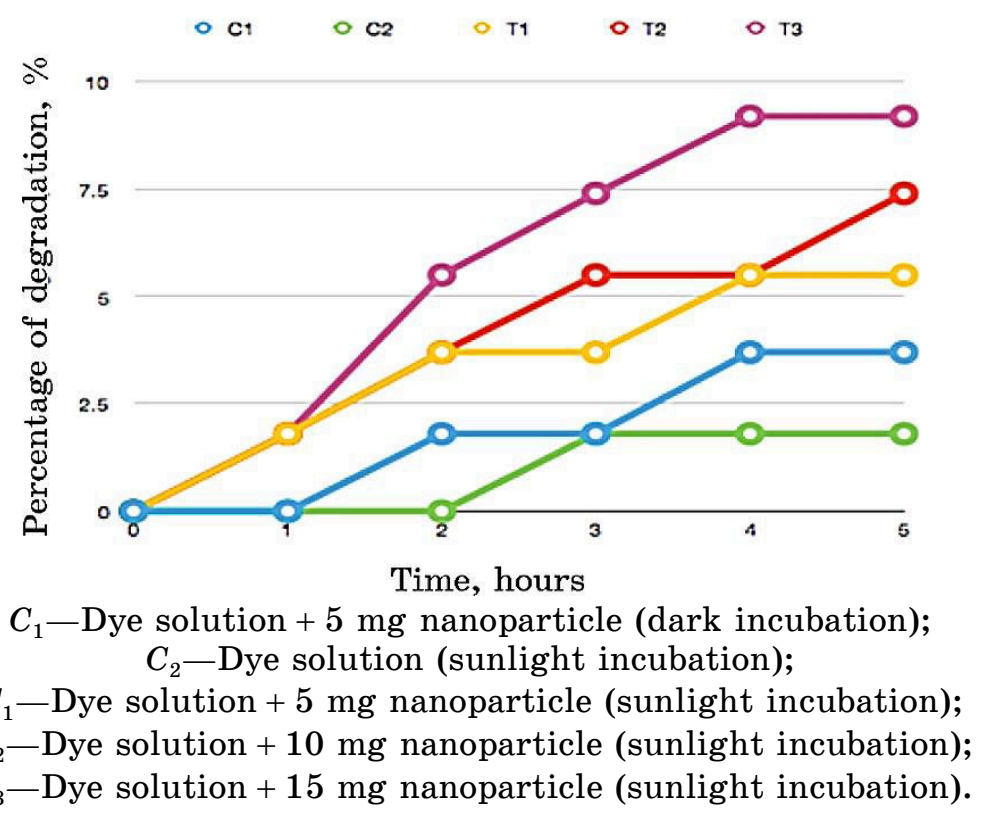

Fig. 12. The graph showing the photocatalytic activity of the chemically synthesized Fe nanoparticle on rhodamine B dye.

\subsubsection{Chemically synthesized Fe nanoparticle}

The photocatalytic activity of chemically synthesized nanoparticle sample 21 represents the activity of nanoparticles for methylene blue dye and 24 represents activity of nanoparticle for rhodamine B dye.

\subsubsection{Methylene blue}

Figure 12 shows the photocatalytic activity of nanoparticle for methylene blue dye. There are three curves representing three different conditions. The first curve $C_{1}$ (control 1) represents dye solution along with $5 \mathrm{mg}$ of nanoparticle kept in dark condition. The second curve $C_{2}$ (control 2) represents dye solution alone kept in direct sunlight. The third curve $\mathrm{T}$ (test) represents dye solution along with $5 \mathrm{mg}$ nanoparticle kept in direct sunlight. The absorbance of the solutions was read at $620 \mathrm{~nm}$ for every hour. The colour of the methylene blue dye at $0^{\text {th }}$ hour and at $5^{\text {th }}$ hour.

From this Figure, the test sample gave maximum degradation percentage of $81 \%$ in 5 hours, and it increases linearly every hour. In the same time, $C_{1}$ and $C_{2}$ have a degradation percentage of $40.4 \%$ and $14.2 \%$, respectively. It is clear that the nanoparticle has a degradation activity against methylene blue dye solution, and its activity or the de- 
grading capability is enhanced by sunlight. The sunlight activates the nanoparticle and enhances its degrading ability. Therefore, chemically synthesized nanoparticle has a degrading activity of $81 \%$ in 5 hours against methylene blue dye. The colour reduction of methylene blue dye in the time span of 5 hours. Studies of Khedr et al. (2016) in photocatalytic activity of Fe nanoparticles on crystal violet dye obtained a degradation efficiency of $86.6 \%$.

\subsubsection{Rhodamine B}

The photocatalytic activity of the nanoparticle against rhodamine $\mathrm{B}$ dye. There are five curves in the graph. The curve $C_{1}$ (control 1) represents dye solution along with $5 \mathrm{mg}$ of nanoparticle kept in dark condition. The curve $C_{2}$ (control 2) represents dye solution alone kept in direct sunlight. The curves $T_{1}, T_{2}, T_{3}$ represent the dye solution along with $5 \mathrm{mg}, 10 \mathrm{mg}, 15 \mathrm{mg}$ of nanoparticle, respectively, kept in direct sunlight. The readings were taken at $540 \mathrm{~nm}$ in a colorimeter for every hour. The images 22 and 23 show the colour of the rhodamine B dye at $0^{\text {th }}$ hour and at $5^{\text {th }}$ hour.

From this Figure, it is evident that the nanoparticle has very lesser activity for rhodamine B than that for methylene blue. Even when the concentration of nanoparticle is increased up to 3 times, the nanoparticle showed maximum degradation percentage of $9.2 \%$ in 5 hours. The nanoparticle has very much less activity against rhodamine B. The Fe nanoparticle has a greater degrading efficiency for simple dyes like methylene blue, and it has much lesser activity or no activity for complex dyes like rhodamine B even when the concentration of nanoparticles is increased three fold. Thus, the photocatalytic activity of Fe nanoparticles is limited and is dependent on how simpler the dye molecule is. The more complex the dye molecule lesser will be the degradation efficiency.

\section{CONCLUSION}

Fe nanoparticles are synthesized biologically using plant extract as reducing agent and chemically using sodium borohydride as reducing agent. The nanoparticles are characterized using various studies. The sizes of nanoparticles are determined using FESEM analysis that rendered $36 \mathrm{~nm}$ for biologically synthesized nanoparticle and $24 \mathrm{~nm}$ for chemically synthesized nanoparticle. The photocatalytic activity of $\mathrm{Fe}$ nanoparticles are studied using methylene blue and rhodamine B dyes. The nanoparticles are able to degrade simple dyes like methylene blue easily in presence of sunlight. However, the Fe nanoparticles are not able to degrade complex dyes like rhodamine $\mathrm{B}$ whatever may be the 
concentration and incubation time. Therefore, the photocatalytic activity of Fe nanoparticles is limited, and it depends on the complexity of the dye being degraded.

\section{REFERENCES}

1. C. Kaushik Roy, K. Sarkar. C. K. Ghosh, Appl. Nanosci. (2015); DOI: $10.1007 / \mathrm{s} 13204-014-0392-4$.

2. Ravindra De Kale and Prerana B. Kane, Textiles and Clothing Sustainability (2016); DOI: 10.1186/s40689-016-0015-4.

3. Sangiliyandi Gurunathan, Eun Su Kim, Jae Woong Han, Jung Hyun Park, and Jin-Hoi Kim, Molecules (2015); DOI: 10.3390/molecules201219860.

4. R. Yuvakkumar, V. Elango, V. Rajendran, and N. Kannan, Digest Journal of Nanomaterials and Biostructures, 6, No. 4: 1771 (2011).

5. Brajesh Kumar, Kumari Smita, Luis Cumbal, and Alexis Debut, Journal of Saudi Chemical Society, 19 (2015); http://dx.doi.org/10.1016/j.jscs.2015.05.008.

6. A. Herrera, A. Reyes, and J. Colina-Márquez, Journal of Physics: Conference Series, 687 (2016); DOI: 10.1088/1742-6596/687/1/012034.

7. Yen Pin Yew, Kamyar Shameli, Mikio Miyake, Noriyuki Kuwano, Nurul Bahiyah Bt Ahmad Khairudin, Shaza Eva Bt Mohamad, and Kar Xin Lee, Nanocommentary, 11, No. 1: 276 (2016); DOI: 10.1186/s11671-016-1498-2.

8. Ting Wang, Xiaoying Jin, Zuliang Chen, Mallavarapu Megharaj, and Ravendra Naidu, Science of the Total Environment, 466: 210 (2014); http://dx.doi.org/10.1016/j.scitotenv.2013.07.022.

9. S. H. Chaki, Tasmira J. Malek, M. D. Chaudhary, J. P. Tailor, and M. P. Deshpande, Advances in Natural Sciences: Nanoscience and Nanotechnology, 6, No. 3: 035009 (2015); doi: 10.1088/2043-6262/6/3/035009.

10. S. Shah, S. Dasgup, M. Chakraborty, R. Vadakkekara, and M. Hajoori, Int. J. Biol. Pharm. Res., 5: 549 (2014).

11. M. H. Khedr, K. S. Abdel Halim, and N. K. Soliman. Materials Letters, 63, No. 6: 7 (2009). 